\title{
TRIPS AGREEMENT AND MALAYSIAN INTELLECTUAL PROPERTY LAWS: DATA EXCLUSIVITY v PATENT
}

\author{
Rahamatthunnisa Mohamed Nizamuddin*
}

\begin{abstract}
This study analyses the provisions of the Trade-Related Aspects of Intellectual Property Rights (TRIPS) Agreement with respect to the various intellectual property protection mechanisms. The main purpose of this study is to demonstrate that Malaysia is a TRIPS compliance country and have established intellectual property laws including the incorporation of data exclusivity laws. This study also illustrates that data exclusivity and patent are two different intellectual property protection mechanisms required under the TRIPS Agreement. Moreover, this study clarifies the misconception that data exclusivity and patents are somehow related; such that data exclusivity is an extension of patent rights and that it is often regarded as a TRIPS-plus provision. The study is conducted based on qualitative research, predicated on primary sources such as the TRIPS Agreement and the various laws with respect to intellectual property in Malaysia. It is further supported by secondary sources from journals and information provided on relevant authorities' websites. The results of the study show that Malaysia is a TRIPS compliance country and that data exclusivity is an intellectual property protection mechanism that is established pursuant to Article 39.3 of the TRIPS Agreement. Hence, this study concludes that member countries of the TRIPS Agreement that have established data exclusivity protection mechanism to protect undisclosed data submitted to their respective authorities for the purpose of marketing approval of pharmaceutical or agricultural chemical products, including Malaysia, are indeed in compliance with the obligation set under Article 39.3 of the TRIPS Agreement.
\end{abstract}

Keyword: Intellectual property, protection mechanism, patent, data exclusivity, TRIPS agreement

* Doctoral Candidate, Ahmad Ibrahim Kulliyyah of Laws, International Islamic University Malaysia. Email: ipexpertmsia@gmail.com.

[Received: 15 July 2019, Accepted: 10 May 2020, Published: 30 June 2020] 


\title{
PERJANJIAN TRIPS DAN UNDANG-UNDANG HARTA INTELEK MALAYSIA: DATA EKSKLUSIVITI v PATEN
}

\begin{abstract}
ABSTRAK
Kajian ini menganalisa peruntukan Perjanjian TRIPS yang memerlukan pewujudan mekanisma perlindungan harta intelek. Tujuan utama kajian ini adalah untuk menunjukkan bahawa Malaysia adalah sebuah negara yang mematuhi Perjanjian TRIPS kerana telah mewujudkan perundangan harta intelek bagi perlindungan harta intelek, termasuk undang-undang berkenaan data eksklusiviti. Kajian ini juga menunjukkan bahawa paten dan data eksklusiviti adalah dua jenis mekanisma perlindungan harta intelek yang harus diwujudkan di bawah Perjanjian TRIPS. Ini akan menjelaskan salah tanggapan bahawa kononnya data eksklusiviti dan paten adalah saling berkait; merupakan lanjutan hak paten; dan merupakan satu mekanisma tambahan kepada Perjanjian TRIPS. Kajian ini adalah berdasarkan kajian kualitatif memandangkan sumber utama kajian adalah Perjanjian TRIPS dan pelbagai perundangan berkenaan mekanisma perlindungan harta intelek di Malaysia, disokong oleh sumber sekunder seperti jurnal dan laman web pihak berkuasa. Hasil kajian ini menunjukkan bahawa Malaysia adalah sebuah negara yang mematuhi Perjanjian TRIPS dan bahawa data eksklusiviti adalah satu mekanisma perlindungan harta intelek yang diwujudkan selaras dengan Fasal 39(3) Perjanjian TRIPS. Ini akan membawa kepada kesimpulan bahawa negara anggota Perjanjian TRIPS yang telah mewujudkan sistem perlindungan data eksklusiviti bagi perlindungan data yang rahsia yang telah diserahkan kepada kepada pihak berkuasa negara masing-masing, bagi tujuan mendapatkan kelulusan pemasaran bagi produk-produk farmaseutikal or pertanian kimia, termasuk Malaysia, adalah selaras dengan kewajipan negara anggota yang diperuntukkan di dalam Fasal 39(3) Perjanjian TRIPS.
\end{abstract}

Kata kunci: Hak intelek, mekanisma perlindungan, paten, data eksklusiviti, perjanjian TRIPS

\section{INTRODUCTION}

The protection of intellectual property rights is a key determinant of economic success in the present era. With the introduction of the Global Innovation Index (GII) which has garnered attention around the world in the recent years, countries have begun concentrating their efforts on intellectual property protection as it is one of the factors 
considered in determining country rankings according to the Index. ${ }^{1}$ One of the criteria considered is based on the country's strength in its intellectual property protection regime. Malaysia is a TRIPS compliant member country and has established strong intellectual property protection mechanisms which are in line with the Agreement on Trade-Related Aspects of Intellectual Property Rights ${ }^{2}$ (TRIPS Agreement). Member countries of the TRIPS Agreement are required to establish the minimum intellectual property protection standards specified therein. Member countries may set a higher protection standard at their own accord, as long as such standards are in line with the TRIPS Agreement. These higher standards of protection, are usually referred to as "TRIPS-plus" provisions". Malaysia's "TRIPS compliance" status was achieved in 2015 after the introduction of the data exclusivity protection mechanism, which is in accordance with Article 39.3 of the TRIPS Agreement, that protects clinical trial data, submitted to regulatory authorities for marketing approval.

It has been the trite argument of developing countries that Article 39.3 of the TRIPS Agreement does not require the inclusion of data exclusivity protection, as opposed to the developed countries. ${ }^{4}$ Some scholars having written in their articles about the link between patent and data exclusivity ${ }^{5}$, hence causing confusion. For example, the article

1 Global Innovation Index accessed July 5, 2019, https://www.globalinnovationindex.org.

2 Agreement on Trade-Related Aspects of Intellectual Property Rights 1994 came into effect on January 1, 1995.

3 "Trade-Related Aspects of Intellectual Property", accessed March 3, 2019, https://www.wto.org/english /tratop_e/trips_e/intel2_e.htm.

4 Animesh Sharma, "Data Exclusivity With Regard to Clinical Data", Indian Journal of Law and Technology 3, (2007): 82-104 at 84.

5 Meir P. Pugatch, "The International Regulations of IPRs in a TRIPS and TRIPS-plus World" Journal of World Investment \& Trade 6, no.3 (June 2005): $431-465$ at 449 and 442 respectively (data exclusivity is an extension of patent system and is a TRIPS-plus provision); Manthan D Janodia', Ajay Chauhan, Shuaib M Hakak, D Sreedhar, V S Ligade and N Udupa, "Data Exclusivity Provisions in India: Impact of Public Health" Journal of Intellectual Property Rights 13, (September 2008): 442-446 at 444 (data exclusivity is a TRIPS-plus provision); Linfong Tzeng, "FollowOn Biologics, Data Exclusivity, and the FDA," Berkeley Technology Law Journal 25, no.1 (2010): 135-158 at 154 (data exclusivity is a complementary protection to patents); Vincent J Roth, "Will FDA Data 
titled "Why Data Exclusivity is the New Patent Protection" is a misconception as it concludes that data exclusivity is an extension of patent rights. These studies have led to a serious misconception in many countries, including Malaysia, that data exclusivity is an extension of patent rights ${ }^{7}$; are correlated to patent rights ${ }^{8}$; and that it is a TRIPS-plus provision, and therefore not required by the TRIPS Agreement $^{9}$ (the Myths). Data exclusivity is an intellectual property

Exclusivity Make Biologic Patents Passe," Santa Clara Computer \& High Technology Law Journal 29, no.2 (2012-2013): 249-304 at 265 (data exclusivity has a direct impact on the patents system); Sean Baird, "Magic and Hope: Relaxing TRIPS-Plus Provisions to Promote Access to Affordable Pharmaceuticals," Boston College Journal of Law and Social Justice 33, no.1 (Winter 2013): 107-146 at 123 (the author, whilst recognizing that the TRIPS Agreement requires data exclusivity, refers data exclusivity laws of the US as a TRIPS-plus provision); Olasupo A. Owoeye, "Data Exclusivity and Public Health under the TRIPS Agreement," Journal of Law, Information and Science 23, no.2 (20142015): 106-133 at 114 (data exclusivity is said to be viewed as conferring patent-like protection); Olasupo A. Owoeye, Intellectual Property and Access to Medicines in Africa: A Regional Framework for Access, (Routledge, 2019) (Chapter 4: data exclusivity is said to be viewed as patent-like protection and is believed to extend patent protection); and Sharma, "Data Exclusivity with Regard to Clinical Data," at 84 (the author acknowledges this confusion and agrees that data exclusivity is a separate intellectual property right from patent and is not an extension of patent rights).

6 Peter J Pitts, "Why Data Exclusivity is the New Patent Protection," Journal of Commercial Biotechnology 16, (2010): 3-4.

7 Pugatch, "The International Regulations of IPRs in a TRIPS and TRIPSplus World" at 449 (data exclusivity is an extension of patent system); and Owoeye, Intellectual Property and Access to Medicines in Africa: A Regional Framework for Access, (Routledge, 2019) (Chapter 4: data exclusivity is said to be viewed as patent-like protection and is believed to extend patent protection).

8 Tzeng, "Follow-On Biologics, Data Exclusivity, and the FDA," at 154 (data exclusivity is a complementary protection to patents); Roth, "Will FDA Data Exclusivity Make Biologic Patents Passe," at 265 (data exclusivity has a direct impact on the patents system); and Owoeye, "Data Exclusivity and Public Health under the TRIPS Agreement," at 114 (data exclusivity is said to be viewed as conferring patent-like protection).

9 Janodia' et al. "Data Exclusivity Provisions in India: Impact of Public Health" at 444 (data exclusivity is a TRIPS-plus provision). 
protection mechanism that has been established by member countries pursuant to Article 39.3 of the TRIPS Agreement. ${ }^{10}$ This article begins by illustrating in general, what intellectual property is and the various intellectual property protection mechanisms required under the TRIPS Agreement. Thereafter, it specifically concentrates and explains the patent and data exclusivity protection mechanisms, to show that these mechanisms are two different intellectual property protection mechanisms that needs to be established independently, under the TRIPS Agreement. ${ }^{11}$ In addressing this point, this article shows that the TRIPS Agreement not only requires member countries to establish the patent system for new inventions (a subject matter of intellectual property); but also need to incorporate a data protection system for clinical and trial data. These data must be submitted to the regulatory authorities, for marketing approval purposes, (a separate intellectual property subject matter). Many countries have established this data protection system via the data exclusivity protection mechanism, including Malaysia. The ultimate aim of this article is to provide a better understanding of the various intellectual property protection mechanisms in Malaysia, and to particularly repudiate the Myths about data exclusivity by addressing the two intellectual property protection mechanisms as separate entities. This study concludes that Malaysia is on the right track in relation to being "TRIPS compliance" and clarifies that data exclusivity is not part of the patent regime as it is an independent intellectual protection mechanism established pursuant to a provision in the TRIPS Agreement.

10 Pei-kan Yang, “Current Development of Canada's Data Exclusivity Regime: How Does Canada React to NAFTA, TRIPS and Dangle Between Pharmaceutical Innovation and Public Health," Asian Journal of WTO \& International Health Law and Policy 4, no.1 (March 2009): 65-91 at 87; Lisa Diependaele, Julian Cockbain, and Sterckx Sigrid, "Raising the Barriers to Access to Medicines in the Developing World - The Relentless Push for Data Exclusivity," Developing World Bioethics 17, no.1 (2017): 11-21 at 13 and Wael Armouti and Mohammad Nsour, "Data Exclusivity for Pharmaceuticals in Free Trade Agreements: Models in Selected United States Free Trade Agreements," Houston Journal of International Law 40, no. 1 (2017): $105-138$ at 115.

11 See Trevor M Cook, The Protection of Regulatory Data in Pharmaceutical and Other Sectors, (London: Sweet \& Maxwell, 2000). 


\section{METHODOLOGY}

This study adopts a doctrinal legal research which is purely a librarybased research, whereby the main source of research is based on primary source viz. the TRIPS Agreement, various intellectual property laws in Malaysia and secondary source such as journals and websites of relevant authorities. This study incorporates theoretical and analytical approaches that investigates the relevant provisions of the TRIPS Agreement to ensure that Malaysia is a TRIPS compliant country by establishing the relevant intellectual property protection mechanisms that include data exclusivity laws which are independent of the patent system.

\section{INTELLECTUAL PROPERTY PROTECTION MECHANISMS}

The TRIPS Agreement is undoubtedly the most significant milestone in ensuring the protection of intellectual property in the twentieth century. ${ }^{12}$ The Agreement was enforced on January 1, 1995 and was established to reduce the distortions and impediments to international trade, taking into consideration the need to promote effective and adequate protection of intellectual property rights and to ensure that measures and procedures to enforce intellectual property rights will not become barriers to legitimate trade. ${ }^{13}$ The term "intellectual property" however, is not defined in any of the international intellectual property agreement including the TRIPS Agreement ${ }^{14}$. Intellectual property is generally interpreted as 'the novel products of human intellectual endeavour'. ${ }^{15}$ As it is a creation of the human mind, intellectual

${ }^{12}$ Daniel Gervais, The TRIPS Agreement - Drafting History and Analysis $3^{\text {rd }}$ ed. (Sweet \& Maxwell, Thomson Reuters (Legal) Limited, 2008), 3.

${ }_{13}$ Preamble to the TRIPS Agreement.

${ }^{14}$ Carlos M. Correa, Trade Related Aspects of Intellectual Property Rights, A Commentary on the TRIPS Agreement (New York: Oxford University Press, 2007), 31.

${ }^{15}$ Hector MacQueen et al., Contemporary Intellectual Property Law and Policy $2^{\text {nd }}$ ed. (New York, United States: Oxford University Press Inc, 2011), 7. See also the World Intellectual Property Organization's, (the authority in charge of matters relating to world intellectual property related matters), website, accessed July 8, 2019, https://www.wipo.int/aboutip/en/, whereby this authority too does not define intellectual property, but refers intellectual property to the creations of the mind, such as inventions; 
property is a tangible asset when reduced into its material form and deserves ownership similar to the ownership of any other forms of property which are in tangible form. ${ }^{16}$ New ideas created by human beings are embodied into objects such as drawings, inventions, designs, music etc. as a new means of expression. ${ }^{17}$ When developed further and commercialized, these expressions require protection from the exploitation by other people. Since competition is unavoidable in any trade or industry, intellectual property laws are introduced to protect the diverse types of expression created by the human intellect ${ }^{18}$ from being exploited without the owner's consent. These laws provide "property-like" protection to the owner of the intellectual property. ${ }^{19}$ Intellectual property requires protection from intellectual property laws, as intellectual property rights can only exist in the presence of legal protection. ${ }^{20}$ With regards to the protection of intellectual property, Malaysia has enacted its laws based on the provisions of the TRIPS Agreement.

According to Article 1.2 of the TRIPS Agreement, the term 'intellectual property' refers to all categories of intellectual property, which are the subjects of Sections 1 through 7 of Part II i.e. the following Sections: -

(a) Section 1: Copyright and Related Rights;

(b) Section 2: Trademarks;

literary and artistic works; designs; and symbols, names and images used in commerce.

16 Richard Stim, Intellectual Property, Patents, Trademarks and Copyrights $2^{\text {nd }}$ ed. (Albany, New York: Delmar West Legal Studies, 2001), 2.

17 Catherine Colston, Principles of Intellectual Property Law (London: Cavendish Publishing Limited, 1999), 1.

18 Colston, Principles of Intellectual Property Law, 1 and MacQueen et al., Contemporary Intellectual Property Law and Policy, 4.

19 William T. Gallagher, ed., Intellectual Property (Hampshire: Ashgate Publishing Limited, 2007), xi and Shayerah Ilias Akhtar and Ian F. Fergusson, "Intellectual Property Rights and International Trade", in Intellectual Property Rights, Background, International Trade Protection, and the Role of Exclusion Orders, ed. Evelyn P. Gilbert (New York: Nova Science Publishers, Inc., 2015), 4.

${ }^{20}$ Melvin Simensky, Lanning G. Bryer and Neil J. Wilkof, eds., Intellectual Property in the Global Marketplace $2^{\text {nd }}$ ed. (New York: John Wiley \& Sons, Inc, 1999), 0.5. 
(c) Section 3: Geographical Indications;

(d) Section 4: Industrial Designs;

(e) Section 5: Patents;

(f) Section 6: Layout-Designs (Topographies) of Integrated Circuits; and

(g) Section 7: Protection of Undisclosed Information

- $\quad$ secret information (Article 39.2); and

- $\quad$ undisclosed test or data (Article 39.3.

A brief discussion for Sections 1, 2, 3, 4, 6 and part of Section 7 (Article 39.2) of the TRIPS Agreement is presented on each of the intellectual property that are created by the human mind and its relevant protection mechanisms, and subsequently, are correlated to their respective intellectual property laws in Malaysia. Sections 5 and part of Section 7 (Article 39.3) will be discussed in the next section of this study by examining the two types of protection mechanisms, in relation to the pharmaceutical industry, in which the differences between patent and data exclusivity as independent forms of intellectual property protection mechanisms under the TRIPS Agreement can be easily identified.

\section{(a) SECTION 1 OF THE TRIPS AGREEMENT ${ }^{21}$}

Section 1 of the TRIPS Agreement requires member countries to provide copyright and related rights ${ }^{22}$ protection for works, performers,

21 Section 1 of the TRIPS Agreement comprises of Articles 9-14.

22 The term "Copyright and Related Rights" appear in the title of Section 1 of the TRIPS Agreement. Article 9 reiterates the protection of the rights of authors of literary and artistic works granted under the Berne Convention for the Protection of Literary and Artistic Works 1886 (as amended on September 28, 1979), and was enforced in November 19, 1984. Articles 11 bis \& 14 of the Berne Convention provides "related rights" protection with respect to broadcasts and films. However, the TRIPS Agreement made no reference of "related rights", other than appearing in the title of "Section 1". Moreover, out of the six Articles under Section 1 of the TRIPS Agreement, only four articles refer to "works" (Articles 10-13), while Article 9 corresponds to "copyright". Therefore, it is prudent to interpret 
producers of phonograms and broadcasting organizations. Copyright is an exclusive right provided by the law, to owners of literary and artistic works and films ${ }^{23}$, to authorize or prohibit the use of their work by others, ${ }^{24}$ while related rights are protection granted to performers for their performance, producers of phonograms for their sound recordings and broadcasting organizations for their broadcast ${ }^{25}$. The intellectual

that "related rights" would mean those rights that are stated in Article 14 with the heading; "Protection of Performers, Producers of Phonograms (Sound Recordings) and Broadcasting Organizations".

23 Article 2.1 of the Berne Convention for the Protection of Literary and Artistic Works 1886 states that the expression "literary and artistic works" shall include every production in the literary, scientific and artistic domain, whatever may be the mode or form of its expression, such as books, pamphlets and other writings; lectures, addresses, sermons and other works of the same nature; dramatic or dramatico-musical works; choreographic works and entertainments in dumb show; musical compositions with or without words; cinematographic works to which are assimilated works expressed by a process analogous to cinematography; works of drawing, painting, architecture, sculpture, engraving and lithography; photographic works to which are assimilated works expressed by a process analogous to photography; works of applied art; illustrations, maps, plans, sketches and three-dimensional works relative to geography, topography, architecture or science.

${ }^{24}$ Kevin Garnett, Jonathan Rayner James, and Gillian Davies, Copinger and Skone James on Copyright $14^{\text {th }}$ ed. (London: Sweet \& Maxwell Ltd, 1999), 1.

25 This interpretation is supported by WIPO whereby in its publication, World Intellectual Property Organization, Understanding Copyright and Related Rights $2^{\text {nd }}$ ed. Publication No.909(E) (Geneva: WIPO, 2016), it states that related rights are traditionally granted to three (3) categories of beneficiaries viz. performers producers of sound recording and broadcasting organizations. This publication illustrates related rights as follows: -

"Related rights, also referred to as neighboring rights, protect the legal interests of certain persons and legal entities that contribute to making works available to the public or that produce subject matter which, while not qualifying as works under the copyright systems of all countries, contains sufficient creativity or technical and organizational skill to justify recognition of a copyright-like property right. The law of related rights deems that the productions that result from the activities of such persons and entities merit legal protection as they are related to the protection of 
property protection mechanism that is required to be established for this purpose is known as the copyright and related rights system. In Malaysia, the copyright system is governed under the Copyright Act $1987^{26}$ (CPA) whereby works which are eligible for copyright protection are specified under Section of 7 of the CPA as literary, artistic, musical, films, sound recording and broadcast. Related rights in Malaysia is also protected under the CPA whereas performers rights are governed under Section 16A. ${ }^{27}$

\section{(b) SECTION 2 OF THE TRIPS AGREEMENT ${ }^{28}$}

Section 2 of the TRIPS Agreement stipulates the needs for member countries to provide protection for trademarks. ${ }^{29}$ A trademark is a sign capable of distinguishing the goods or services of one undertaking from those of other undertakings. ${ }^{30} \mathrm{~A}$ sign is defined to include words, names, letters, numerals, figurative elements, combination of colours and any combinations of the signs ${ }^{31}$. The intellectual property protection mechanism suggested to be established under this Section, is a trademark registration system. In Malaysia, registration of trademark is governed by the Trademarks Act $2019^{32}$ whereby a trademark is defined therein as "any sign capable of being represented graphically which is capable of distinguishing goods or services of one undertaking from those of other undertakings". 33

works of authorship under copyright.", accessed May 4, 2019, http://www.wipo.int/edocs/pubdocs/en/wipo_pub_909_2016.pdf.

${ }^{26}$ Copyright Act 1987 (Act 332) enforced on 01 December 1987.

27 The Copyright Act 1987 (CPA) does not use the words "related rights". Under the CPA, copyright also includes sound recordings and broadcasts, which according to WIPO are beneficiaries of related rights. Immaterial of these "labeling" issues, the CPA provides protection for both copyright (works under Section 7) and related rights (performers under Section 16A).

${ }^{28}$ Section 2 of the TRIPS Agreement comprises of Articles 15-21.

29 Article 15 of the TRIPS Agreement.

30 Article 15.1 of the TRIPS Agreement.

31 Article 15.1 of the TRIPS Agreement.

32 Trademarks Act 2019 (Act 815) enforced on 09 December 2019.

${ }^{33}$ See Section 3(1) of the Trademarks Act 2019. 


\section{(c) SECTION 3 OF THE TRIPS AGREEMENT ${ }^{34}$}

Section 3 of the TRIPS Agreement requires member countries to provide protection for geographical indications. ${ }^{35}$ Geographical indications are indications which identify a good as originating in the territory of a country, where a given quality, reputation or other characteristic of the good is essentially attributable to its geographical origin. ${ }^{36}$ The TRIPS Agreement merely states that member countries shall protect geographical indications, without specifying any means or action that needs to be taken. This suggests that member countries are free to determine the protection mechanism for geographical indications. In Malaysia, geographical indications ${ }^{37}$ are protected under the Geographical Indications Act 2000 (GIA) ${ }^{38}$, regardless of whether or not the indications are registered under the GIA. ${ }^{39}$

\section{(d) SECTION 4 OF THE TRIPS AGREEMENT ${ }^{40}$}

Section 4 of the TRIPS Agreement requires member countries to provide protection for industrial designs. ${ }^{41}$ Industrial designs are features of shape, configuration, pattern or ornament applied to an article by any industrial process, being features which in the finished article appeal to the eye but does not include a method of construction, or features of shape or configuration which are dictated solely by function. ${ }^{42}$ The TRIPS Agreement does not specify a particular protection mechanism for the protection of industrial designs. The provisions of the TRIPS Agreement suggest that member countries are required to protect industrial designs by enacting industrial design laws

34 Section 3 of the TRIPS Agreement comprises of Articles 22-24.

35 Articles 22 and 23 of the TRIPS Agreement.

36 Article 22.1 of the TRIPS Agreement.

37 Section 2 of the Geographical Indications Act 2000 (GIA) has a similar definition of geographical indications as per the TRIPS Agreement.

38 Geographical Indications Act 2000 (Act 602) enforced on 15 August 2001.

39 Section 3 of the GIA.

40 Section 4 of the TRIPS Agreement comprises of Articles 25-26.

41 Article 25 of the TRIPS Agreement.

42 See the full definition of "industrial designs" under Section 3 of the Industrial Design Act 1996 (IDA). The TRIPS Agreement does not define what industrial design is. Article 25.1 merely states that protection shall be granted for industrial designs that are new or original. 
or copyright. This implies that members are free to determine the protection mechanism for industrial designs. In Malaysia, to ensure the protection of an industrial design, it has to be registered under the Industrial Designs Act 1996. ${ }^{43}$ Although some countries protect unregistered designs, ${ }^{44}$ protection of unregistered designs is not available in Malaysia.

\section{(e) SECTION 6 OF THE TRIPS AGREEMENT ${ }^{45}$}

Section 6 of the TRIPS Agreement requires member countries to provide protection for layout-designs of integrated circuits. ${ }^{46}$ Layoutdesign means the three-dimensional disposition, however expressed, of the elements, at least one of which is an active element, and of some or all of the interconnections of an integrated circuit, or such a threedimensional disposition prepared for an integrated circuit intended for manufacture. ${ }^{47}$

Integrated circuit is a product, in its final form or an intermediate form, in which the elements, at least one of which is an active element, and some or all of the interconnections are integrally formed in and/or on a piece of material and which is intended to perform an electronic function. ${ }^{48}$ In short, layout-designs of integrated circuits are simply referred to as microchips or 'chips', and have continued to be an integral element in the information technology industry. ${ }^{49}$ The TRIPS Agreement does not specify the type of protection mechanism that is

${ }^{43}$ Industrial Designs Act 1996 (Act 552) enforced on 1 September 1999.

${ }^{44}$ United Kingdom is a country that protects unregistered designs. See Paul Torremans, Holyoak and Torremans Intellectual Property Law, $6^{\text {th }}$ ed., (New York, United States: Oxford University Press Inc., 2010), 360-379.

${ }^{45}$ Section 6 of the TRIPS Agreement comprises of Articles 35-38.

46 Article 35 of the TRIPS Agreement.

47 Article 2 of the Treaty on Intellectual Property in Respect of Integrated Circuits 1989. Definition of layout-designs of integrated circuit is not provided under the TRIPS Agreement. However, Article 35 provides reference to layout-designs of integrated circuit in the Treaty on Intellectual Property in Respect of Integrated Circuits, which was adopted in 1989, however has yet to be enforced.

48 Article 2 of the Treaty on Intellectual Property in Respect of Integrated Circuits 1989.

49 UNCTAD-ICTSD, Resource Book on TRIPS and Development (New York: Cambridge University Press, 2005) at 506. 
required to protect layout-designs of integrated circuits. The Agreement merely states that member countries are required to protect layout-designs of integrated circuits. Hence, it is upon the discretion of member countries to enforce the right protection mechanism for this intellectual property. In Malaysia, layout- designs of integrated circuits is protected by the Layout-Designs of Integrated Circuits Act $2000^{50}$ and does not require prior registration of that intellectual property.

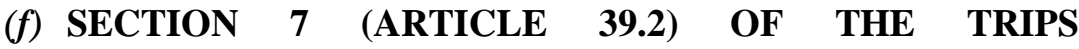 AGREEMENT ${ }^{51}$}

Article 39 of the TRIPS Agreement states the following: -

1. In the course of ensuring effective protection against unfair competition as provided in Article 10bis of the Paris Convention $(1967)^{52}$, Members shall protect undisclosed information in accordance with paragraph 2 and data submitted to governments or governmental agencies in accordance with paragraph 3 .

2. Natural and legal persons shall have the possibility of preventing information lawfully within their control from being disclosed to, acquired by, or used by others without their consent in a manner contrary to honest commercial practices so long as such information:

a) is secret in the sense that it is not, as a body or in the precise configuration and assembly of its components, generally known among or readily accessible to persons within the circles that normally deal with the kind of information in question;

b) has commercial value because it is secret; and

c) has been subject to reasonable steps under the circumstances, by the person lawfully in control of the information, to keep it secret.

3. Members, when requiring, as a condition of approving the marketing of pharmaceutical or of agricultural chemical products

${ }^{50}$ Layout-Designs of Integrated Circuits Act 2000 (Act 601), enforced on 15 August 2000.

${ }^{51}$ Section 7 of the TRIPS Agreement is in respect of Article 39. However, for purposes of this part, focus is on Article 39.2. Article 39.3 will be addressed in a separate part.

52 Paris Convention for the Protection of Industrial Property 1883 (as amended on September 28, 1979), entered into force on June 3, 1984. 
which utilize new chemical entities, the submission of undisclosed test or other data, the origination of which involves a considerable effort, shall protect such data against unfair commercial use. In addition, Members shall protect such data against disclosure, except where necessary to protect the public, or unless steps are taken to ensure that the data are protected against unfair commercial use.

The provisions of Article 39.2 dictates that member countries must protect secret information that have commercial values, whereas Article 39.3 dictates that member countries must protect undisclosed test or data that have been submitted for the purpose of obtaining marketing approval. The type of intellectual property that is referred to in Article 39 is information that has the tendency of being confidential, as specified under Article 39.2. Article 39.3 will be addressed in the following section of this study. According to Article 39.2, member countries must protect any information which are prone to confidentiality or any information that are meant to be secret. However, the provision does not provide any specific protection mechanism for such information. In Malaysia, there are no legislation that protect trade secrets or confidential information..$^{53}$ Nevertheless, in the event that there is a breach of confidential information, a common law action for breach of confidential information is available to owners of the confidential information. ${ }^{54}$

\section{SECTION 5 OF THE TRIPS AGREEMENT ${ }^{55}$}

Section 5 of the TRIPS Agreement requires member countries to provide patent protection for inventions. ${ }^{56} \mathrm{New}$ inventions are the intellectual property of their owners as they are created by the human

53 See Section 21(3) of the Competition Act 2010 (Act 712) enforced on 01 January 2012 in relation to competition, which does not protect confidential information but makes it an offence to disclose or make use of confidential information which is defined to mean trade, business or industrial information that belongs to any person that has economic value and is not generally available to or known by others.

54 See Yeohata Macheneries Sdn Bhd \& Anor v Coil Master Sdn Bhd \& Ors [2015] 6 MLJ 810 on principles of confidential information.

55 Section 5 of the TRIPS Agreement comprises of Articles 27-34.

56 Article 27.1 of the TRIPS Agreement. 
mind and member countries are bound under the TRIPS Agreement to establish a patent system to protect inventions which are new, involve inventive step and are capable of industrial application. ${ }^{57}$ The main purpose of the patent system's structure is to stimulate invention, innovation and diffusion by giving the owner a competitive advantage against imitators. ${ }^{58}$ In general, patents are grants issued to inventors for new inventions. There is no definition provided for patents under the TRIPS Agreement. ${ }^{59}$ In the United Kingdom, the term patent is said to have been derived from "Letters Patent", from the old English system which signified the grant of some privileges through open letters bearing seals of sovereignty, i.e. the King's Great Seal, for the subjects to take note of, ${ }^{60}$ in respect of new creations. The grant of a patent is a monopoly right given to the owner, to exploit his invention for a certain period of time ${ }^{61}$ and this grant comes with a price. Price means "full disclosure of the invention to the public" in exchange for a grant of patent. As per Lord Mansfield: ${ }^{62}$

...the law requires as the price the patentee must pay to the public for his monopoly, that he should, to the very best of his knowledge, give the fullest and most sufficient description of all the particulars on which the effort depends.

57 Article 27.1 of the TRIPS Agreement.

58 Toshiko Takenaka, Patent Law: A handbook of Contemporary Research, (Cheltenham, UK: Edward Elgar Publishing, 2008), 68, EBSCOhost, accessed July 5, 2019.

59 Article 27 of the TRIPS Agreement does not define patent, but lists out the criteria that qualifies for a patent. Patents are also not defined under the Paris Convention for the Protection of Industrial Property 1883.

60 Richard Miller, Guy Burkill, Colin Birss, and Douglas Campbell, Terrel on the Law of Patents (London: Sweet \& Maxwell, 2011): 1. See also, Matthew Fisher, Fundamentals of Patent Law Interpretation and Scope of Protection (North America, US and Canada: Hart Publishing, 2007): 23, where the author states that although the exact origin of the modern patent law is unknown, patent model was not in any way peculiar to England.

61 Staniforth Ricketson, The Law of Intellectual Property (Sydney: The Law Book Company Limited, 1984) at 859. See also Nicholas J. Nissing, Patents and Strategic Inventing, The Corporate Inventor's Guide to Creating Sustainable Competitive Advantage (Mc Graw Hill, 2013): 6.

62 See Liardet v Johnson [1778] 1 W.P.C. 53. 
David I Bainbridge ${ }^{63}$ has summarized this when he wrote:

What the patent system does is to guarantee a limited term of protection in return for the investor's agreement to disclose details of his invention and, ultimately, to abandon his property right in it.

The concept of patent is further illustrated by Philip W. Grubb ${ }^{64}$ as follows:

The consideration for the granting of patents, in general, is the benefit which results to the state by technological progress as represented by the commercialization of inventions. The connection between the granting of patents and the commercialization of inventions is simply that the existence of patents rights removes part of the risk involved in investment in a new development. Who, after all, would be willing to invest large sums of money in a new project if he knew that an imitator could copy his product as soon as it was marketed, without incurring any research costs? The justification for the patent system is that it provides an incentive for investment in new ideas, without which technological development would be much slower and more difficult.

An invention being the creation of the human mind, is a form of intellectual property and intellectual property law, through the patent protection mechanism protects such inventions, provided that such inventions comply with the requirements of the law. ${ }^{65}$ The patent system is beneficial to all parties as the publication of information allows the dissemination of technical information to the public. Furthermore, through invention, wealth and employment are created and maintained. ${ }^{66}$ In Malaysia, patent is governed by the Patents Act 1983 (PA). ${ }^{67}$ An invention simply means an idea of an inventor which permits in practice the solution to a specific problem in the field of

${ }^{63}$ David I. Bainbridge, Intellectual Property $9^{\text {th }}$ ed. (Pearson Education Limited, 2012) at 394. For a better understanding of Locke's theory on property right, refer to Peter Drahos, A Philosophy Of Intellectual Property (England : Dartmouth Publishing, 1996): 41-68.

${ }^{64}$ Philip W. Grubb, Patents for Chemicals. Pharmaceuticals and Biotechnology, Fundamentals of Global Law, Practice and Strategy $4^{\text {th }}$ ed. (Oxford: Oxford University Press, 2004): 14.

${ }^{65}$ Stim, Intellectual Property, Patents, Trademarks and Copyrights, 2.

${ }^{66}$ Bainbridge, Intellectual Property, 390.

${ }^{67}$ Patents Act 1983 (Act 291), enforced on 1 October 1986. 
technology. ${ }^{68}$ Patents are granted for inventions that fulfill the 3 criteria which are; new, inventive and has industrial applicability. ${ }^{69}$ However, inventions involving plant varieties are not protected under the patent system, but is protected under the plant varieties protection registration system, governed by the New Plant Varieties Act 2004. ${ }^{70}$

\section{PATENT RELATED SUBJECT MATTERS}

In the pharmaceutical industry, the problem revolve around the two main players; the first being the original drug manufacturers of original and new drugs, and the second being the generic drug manufacturers, who most of the time, copy the drugs produced by the original drug manufacturers and sells them at a reduced price. ${ }^{71}$ The originators develop new drugs, whereas the generics produces bioequivalent version of that drug $^{72}$. It is the infamous arguments of the generic manufacturers that intellectual property protection causes problem of access to cheaper medicines. ${ }^{73}$ However, there is no doubt that intellectual property is a form of property ${ }^{74}$ and since everyone has a right to own and protect their property, it is therefore justified for the originators to protect their property, in the form of new drug invented. As with all intellectual property protection mechanisms, when creativity blossoms, innovation progresses. This ultimately leads to the flourishment of economic development of a country.

68 Section 12 of the PA.

69 Section 11 of the PA.

70 New Plant Varieties Act 2004 (Act 634), enforced on 20 October 2008.

71 Valerie Junod, "Drug Marketing Exclusivity Under United States and European Union Law," Food and Drug Law Journal 59, no.4 (2004):479518 at 479.

72 Molly Anning, "Pay for Delay": Legitimate Conduct to Defend Valid Patent Rights or Anticompetitive Behaviour?," Victoria University of Wellington Law Review 49, no.1 (May 2018):25-52 at 25.

73 See for example Srividhya Ragavan, "The Drug Debate: Data Exclusivity is the New Way to Delay Generics," Connecticut Law Review 50, (20172018): 1-14 at 1 and Robin Feldman and Evan Frondorf, "Drug Wars: A New Generation of Generic Pharmaceutical Delay," Harvard Journal on Legislation 53, no.2 (Summer 2016): 499-562.

74 See Peter Drahos, A Philosophy Of Intellectual Property (England : Dartmouth Publishing, 1996): 41-68. 
The creation of a new drug is the intellectual property of the original drug manufacturers as it is considered as a new invention and is protected, via patent. The invention is the result of long, and costly research and development by pharmaceutical companies. ${ }^{75}$ During the process of creating the new drug, the original manufacturers would have collected data that would include information on its chemistry and effectiveness. Most countries require the original drug manufacturers to show the efficacy of the drugs created to obtain marketing approval prior to entering the market. Both these data and invention are the intellectual property of the original drug manufacturer. Original drug manufacturers usually protect their intellectual property rights in the new drugs by obtaining patents thereto. Due to patent protection, generic drug manufacturers are restrained from copying and producing the new drugs for as long as the patent is in force. ${ }^{76}$

75 Corinne Sauer and Robert M. Sauer, "Is it possible to have cheaper drugs and preserve the incentive to innovate? The benefits of privatizing the drug approval process," Journal of Technology Transfer 32, (2007): 509-524 at 509, http://dx.doi.org/10.1007/s10961-007-9036-0. Although different figures of costs are quoted by various sources, the costs are still exorbitant. It stated that the Association of the Pharmaceutical Research and Manufacturers of America (PhRMA) reported an estimated \$33.2 billion on R\&D expenditures in 2003 and the European Federation of Pharmaceutical Industries and Associations (EFPIA) reported R\&D investment of 21.1 billion euros for the same year.

76 This is subjected to the Bolar Provision introduced in many countries, where the provision does not make it an act of infringement of patent for the generic drug manufacturer to submit an application for marketing approval of a copied patented drug a few months prior to the expiry of the original drug manufacturer's patent. This is to ensure that the copied drug can enter the market immediately upon the expiry of the patent for the drug. In Malaysia, this provision is included in Section 37(1A) of the Patents Act 1983. In addition, Article 33 of the Agreement on Trade-Related Aspects of Intellectual Property 1994 (TRIPS Agreement) requires member countries to provide a minimum of 20 years protection from the filing date. In Malaysia, Section 35 of the Patents Act 1983 states that a patent shall be valid for 20 years from the filing date. This right is in accordance to Article 31 of the TRIPS Agreement with respect to the use without authorization of the right holder. In Malaysia, this right is subjected to Part X of the Patents Act 1983 for compulsory licenses, and Section 84 of the Patents Act 1983 for rights of Government. 
Under the patent protection, the original drug manufacturer has the exclusive right to exploit his invention, ${ }^{77}$ and has the right to prevent others from making the drug without consent. ${ }^{78}$ A generic drug manufacturer can market the copied version of the new drug only after the expiry of the patent for that drug, which is 20 years from its filing date. ${ }^{79}$ Conversely, the patent is granted in exchange for information on the development of the new drug. A patent is not granted for the information and data obtained during the "testing and trials conducted to examine the efficacy of the new drug'. These information and data are not revealed in a patent application, and hence, are not required to be disclosed. Since regulatory authorities in some countries require the submission of these information and data to secure a marketing approval, the TRIPS Agreement asserts that the Governments of countries requiring such marketing approval are responsible to protect these information and data. Moreover, the information and data are to be protected not through the patent system but through a data protection system. This protection mechanism will be further discussed in the following section.

Through the years, the patent system has gradually evolved to various patent-related rights that are established by countries around the world to attract innovation and ensure sustainability. In this section, issues surrounding patents such as patent term restoration and second medical use will be discussed to differentiate the extension of patent rights and TRIP-plus provisions. This will provide a better understanding between extension of patent rights and data exclusivity.

77 Section 36 of the PA.

${ }^{78}$ Section 58 of the PA.

${ }^{79}$ Article 33 of the TRIPS Agreement requires member countries to provide a minimum of 20 years protection from the filing date. In Malaysia, Section 35 of the Patents Act 1983 states that a patent shall be valid for 20 years from the filing date. This right is in accordance to Article 31 of the TRIPS Agreement with respect to the use without authorization of right holder. In Malaysia, this right is subjected to Part X of the Patents Act 1983 for compulsory licenses, and Section 84 of the Patents Act 1983 for rights of Government. 


\section{(a) PATENT TERM RESTORATION}

The main purpose of the patent system's structure is to stimulate invention, innovation and diffusion, by giving the owner a competitive advantage against imitators. ${ }^{80}$ Once the patent has expired, the invention and all its information are open to public which allows anyone to produce the invention without any restrictions. As discussed above, the general concept of the patent protection is that once a patent application has been filed, the owner of the invention may immediately market the invention and when the patent is granted for the invention, he would obtain absolute right to exploit his invention for an exclusive period of 20 years from the filing date of the patent application. However, the owners of a pharmaceutical product are not granted this right as pharmaceutical product are not allowed to be placed in the market without first obtaining a marketing approval from the drug regulatory authority. ${ }^{81}$ An application for marketing approval of a new drug is carried out after the filing of a patent application due to the novelty requirements of the patent system.

Therefore, owners of pharmaceutical products have argued that due to the long duration of obtaining marketing approval for the pharmaceutical product, ${ }^{82}$ the period of absolute monopoly exploitation privileges awarded to them is not the same as the privileges awarded to the owner of a normal patented product that does not require marketing approval. Specifically, there is a discrepancy in the time period for exclusivity rights awarded under the patent protection. For example, if marketing approval for a pharmaceutical product is given 8 years after the date of the patent for a new drug is filed, the owner of the patented pharmaceutical product would only have the remaining 12 years of absolute monopoly exploitation privilege. Consequently, some countries have introduced the patent term restoration system that allows pharmaceutical companies to obtain additional time for patent protection caused by the delay of obtaining approval by the drug marketing approval authority. The United States of America is one of

80 Takenaka, Patent Law, 68.

81 Grubb, Patents for Chemicals, 157.

82 For further understanding of marketing approval of pharmaceutical products, visit the relevant websites of product approval systems for drugs on grounds of safety and efficacy, as required by the Food and Drug Authority of the United States and the National Pharmaceutical Regulatory Agency, Malaysia, prior to such product entering market. 
the countries that have implemented this system. However, Malaysia has not included the patent term restoration under its patent system. The patent term restoration is merely an extension to the patent system, and is considered as a TRIPS-plus provision.

\section{(b) SECOND MEDICAL USE}

Second medical use simply means the new therapeutic use of a known chemical substance or compound. ${ }^{83}$ In the pharmaceutical field, different uses of a known molecule may be protected by different patents, although its first application may already be covered by a patent. ${ }^{84}$ Certain issues have arisen pertaining to the purpose of awarding patents for second or further medical use when an earlier patent has already been granted for the same compound, however, with a different application. Eventually, generic drug manufacturers introduced the concept of "evergreening" of patents, from the patents awarded to the original drug manufacturers..$^{85}$ It is difficult to obtain a second or further medical use patent as the processes to procure a patent for any invention, particularly for the second or further use of a known molecule, must fulfill the three main criteria of patentability. Although the drug with a new therapeutic use may be contemporary, it must fulfill the requirements to be patentable. Different countries allow patentability of second medical use based on different criteria. In

${ }^{83}$ Gabriel Counzo and Daniela Ampollini, "Generic Medicines and Second Medical Use Patents: Litigation or Regulation? An Overview of Recent European Case Law and Practice,", International Review of Intellectual Property and Competition Law 49, (October 2018): 895-915, https://doi.org/10.1007/s40319-018-0764-5.

${ }^{84}$ Selma Unlu and Gulay Goksu, "Second Medical Use Patents and the Skinny Label Issue," Managing Intellectual Property, no. 257, March 2016, 121.

85 Basheer Shamnad, "Trumping TRIPS: Indian Patent Proficiency and the Evolution of an Evergreening Enigma," Oxford University Commonwealth Law Journal 18, no.1 (2018): 16-45, https://doi.org/10.1080/14729342.2018.1455479; Joli Patel, “India's Crack down on the Practice of Pharmaceutical Evergreening : The 2013 Novartis Decision," University of Missouri Kansas City Law Review 85, no.2 (Winter 2017): 503-538 and Julia E. Hill, "Changes to Intellectual Property Policy in South Africa: Putting a Stop to Evergreening?," Expert Opinion on Therapeutic Patents 24, (2014): 839-843, https://doi.org/10.1517/13543776.2014.931376. 
Malaysia, patent for second medical use is granted if the criteria of invention and patentability requirements subjected to PA are fulfilled. The concept of second medical use is merely a patent related matter on issues surrounding patentability, and is not an intellectual property protection mechanism, unlike the patent or data exclusivity mechanisms.

\section{SECTION 7 (ARTICLE 39.3) OF THE TRIPS AGREEMENT ${ }^{86}$}

Article 39 of the TRIPS Agreement provides: -

1. In the course of ensuring effective protection against unfair competition as provided in Article 10bis of the Paris Convention (1967), Members shall protect undisclosed information in accordance with paragraph 2 and data submitted to governments or governmental agencies in accordance with paragraph 3 .

2. Natural and legal persons shall have to keep it secret.

3. Members, when requiring, as a condition of approving the marketing of pharmaceutical or of agricultural chemical products which utilize new chemical entities, the submission of undisclosed test or other data, the origination of which involves a considerable effort, shall protect such data against unfair commercial use. In addition, Members shall protect such data against disclosure, except where necessary to protect the public, or unless steps are taken to ensure that the data are protected against unfair commercial use.

The first part of Article 39.3 requires member countries to protect all undisclosed data submitted to them by the manufacturers and distributors of pharmaceutical, or agricultural chemical products that contain a new chemical entity against unfair commercial use. The second part of Article 39.3 imposes an obligation on member countries to keep all data from being disclosed and that marketing approval must first be obtained from the regulatory authorities before the products can be marketed. Before any drugs can be marketed, they must pass the safety and efficacy rules set by the health authority in the country for which the drug will be marketed. In addition, data supporting the safety

${ }^{86}$ Section 7 of the TRIPS Agreement is in respect of Article 39. However, for purpose of this article, this part will focus on Article 39.3. Article 39.2 has been addressed in paragraph (f) of Section B of this article. 
and efficacy of the drug must be submitted to the health authority. This is in accordance with the guidelines set for safety and efficacy of drugs that is imposed by the World Health Organization (WHO) ${ }^{87}$ The submission of the data is one of the requirements put forth, regardless if the drug is protected by its patent system. Essentially, Article 39.3 of the TRIPS Agreement dictates the protection of the data submitted to drug authorities for the purposes of marketing approval, with no mention on the patent system. It is noteworthy that the term 'data exclusivity' is not stated within the provisions of Article 39.3, although the term 'data exclusivity' has always been associated with Article $39.3 .^{88}$

In many cases, test data obtained from clinical trials have been tediously recorded and collected with tremendous effort. ${ }^{89}$ The wealth of information obtained through research of trials and errors of a drug, from the very inception until the drug is fully developed, have been of vital importance to the inventors as vast amounts of time, money and effort were spent (this wealth of information shall hereinafter be referred to as "Undisclosed Data"). Undisclosed Data is the intellectual property of the original drug manufacturers as they are created by the human mind, and under the following provisions of Article 39.3. of the TRIPS Agreement, such Undisclosed Data are required to be protected from being used or relied upon by the generic manufacturers that seek marketing approval for their generic version of the drug. ${ }^{90}$

Different drug authorities would require different types or versions of Undisclosed Data to authorize marketing approval. Typically, all authorities will only grant approval provided that the data submitted

87 World Health Organization (WHO), accessed March 3, 2019, www.who.int.

${ }^{88}$ Cook, The Protection of Regulatory Data in Pharmaceutical and Other Sectors. See also the history of evolution of data exclusivity argued in relation to Article 39.3 of the TRIPS Agreement in Daniel Gervais, The TRIPS Agreement - Drafting History and Analysis $3^{\text {rd }}$ ed. (Sweet \& Maxwell, Thomson Reuters (Legal) Limited, 2008), 3 and Gabriele Spina Ali, "TRIPS and the Disclosure of Clinical Information: A Intellectual Property Perspective of Data Sharing," Journal of World Intellectual Property 20, (2017): 24-56 at 24, https://doi.org/10.1111.jwip.12071.

${ }^{89}$ Gervais, The TRIPS Agreement, 428.

90 Srividhya Ragavan, "The Re(Newed) Barrier to Access to Medication: Data Exclusivity," Akron Law Review 51, no.4 (2017): 1163-1196 at 1167. 
supports the claim that the drug is safe and effective. In Malaysia, the National Pharmaceutical Regulatory Authority, under the purview of the Drug Control Authority of the Ministry of Health, has placed a set of data requirements that are required as supporting components in evaluating the application for a drug registration, which are; administration data, product quality, product safety, and product efficacy. ${ }^{91}$ These Undisclosed Data which are submitted for approval is required as evidence to ensure that the drug invented is of high quality, safe and effective. Furthermore, it is understandable that drug innovators would have been engaged in tedious research and tests which are very $\operatorname{costly}^{92}$, and therefore, would demand that such information receive a form of protection by the regulatory bodies.

In contrast to Section 5 of the TRIPS Agreement that specifically requires a particular intellectual property protection mechanism to be set up by member countries, such as the patent protection system, Article 39.3 of the TRIPS Agreement merely states that member countries are required to protect Undisclosed Data. In fulfilling this obligation, most member countries have introduced the data exclusivity ${ }^{93}$ protection mechanism to protect Undisclosed Data. Data exclusivity refers to a practice whereby for a fixed period of time, drug regulatory authorities do not allow the registration files of an originator to be used to register a therapeutically equivalent generic medicine. ${ }^{94}$ Essentially, data exclusivity is a mechanism protecting the Undisclosed Data that belongs to a manufacturer of a drug from being used by the

91 "Drug Registration Guidance Document", National Pharmaceutical Control Bureau, Ministry of Health, $2^{\text {nd }}$. Ed. (2016, revised January 2019): 118, accessed July 10, 2019, https://www.npra.gov.my/images/DrugRegistration-Guidance-

Document/2016/Jan2016/Complete_DRGD_JAN_2016.pdf.

92 Wayne Winegarden, "The Pharmaceutical Pricing Process Over Time: Balancing the Competing Needs of Rewarding Innovation and Promoting Competition," American Journal of Medical Research 2, (2015): 59-79.

93 See Jayashree Watal, Intellectual Property Rights in the WTO and Developing Countries, (The Hague; Boston: Kluwer International Law, 2001). According to the author, during the negotiations of the TRIPS Agreement in Brussels, the purpose of Article 39.3 was to permit a period of market exclusivity for a period of five (5) years to originators of the test data for products that utilized new chemical entities, even if these entities were not eligible for patent protection.

${ }^{94}$ Sharma, "Data Exclusivity", 83. 
regulatory authorities to approve the application for a generic version of the original drug. ${ }^{95}$ Different countries provide different durations for the protection of these Undisclosed Data. In Malaysia, the Undisclosed Data are protected by the data exclusivity system established through the Directive on Data Exclusivity in Malaysia, under Regulation 29 of the Control of Drugs and Cosmetics Regulations 1984, No.2, Year 2011. ${ }^{96}$

\section{DATA EXCLUSIVITY v PATENT}

Therefore, it is clear that data exclusivity is an intellectual property protection mechanism that exists independently from the patent system and is a system established in accordance with Section 7 of the TRIPS Agreement viz. Article 39.3, where member countries are required to protect Undisclosed Data. Data exclusivity has often been confused with "second medical use", where the latter is mostly related to the patent system. Moreover, data exclusivity has also been misunderstood with regards to its association to patents due to certain scholars using terms such as "patent-like protection,"97 "pseudo-patent"98 and

95 For a better understanding on data exclusivity, see Muhammad M Hammami, et. al, "Generic-Reference and Generic-generic Bioequivalence of Forty-two, Randomly-selected, On-market Generic Products, of Fourteen Immediate-release of Oral Drugs," BMC Pharmacology \& Taxology 18, (2017), https://doi-org.ezlib.iium.edu.my/10.1186/s40360017-0182-1; Tzeng, "Follow-on Biologics"; Erika Lietzan, "The Myths of Data Exclusivity," Lewis \& Clark Law Review 20, (2016):91-164 at 91 and Ulrich Storz, "Patent Lifecycle Management, Supplementary Protection Certificates, and Data Exclusivity in Biopharmaceutics," Biopatent Law: Patent Strategies \& Patent Management, (2012): 25-41, https://doi.org/10.1007/978-3-642-24846-7_3.

96 Directive on Data Exclusivity in Malaysia, under Regulation 29 of the Control of Drugs and Cosmetics Regulations 1984, No.2, Year 2011, was enforced on 1 March 2011.

97 Rebecca S. Eisenberg, "The Role of the FDA in Innovation Policy", Michigan Telecommunications and Technology Law Review 13, no.2 (2007): $345-388$ at 361.

98 Robert Alan Hess, "Excavating Treasure from the Amber of the Prior Art: Why the Public Benefit Doctrine is Ill-Suited to the Pharmaceutical Sciences", Food and Drug Law Journal 66, no.1 (2011): 105-120 at 107. 
"patents style protection" before, patents are granted for the exchange of detailed information on the invention, and is considered a form of encouragement for development. Patents are not granted for information and data obtained in the 'testing and trials conducted to examine the efficacy of the new drug'. It is the data exclusivity protection mechanism that protects the Undisclosed Data and is intended for the purpose of submitting information to the relevant authorities for marketing approval. Data exclusivity does not encourage development as Undisclosed Data are protected from the public to ensure complete monopoly by the original manufacturers of the drug. This clearly shows the differences between the patent system and data exclusivity protection mechanism. Therefore, this study proves that there has been a misconception between the two systems, and that both the patent system and data exclusivity must be considered as separate entities in the TRIPS Agreement. From the above explanation, it is submitted that the Myths are a fallacy.

\section{CONCLUSION}

Intellectual property is an evolving subject matter and is mainly due to the rapid growth of new technology over the years. The protection of intellectual property rights is different across the region, and as such, it is important to have a strong understanding of intellectual property rights in Malaysia. Malaysia has continued to be a TRIPS compliant member country, and has established all the 9 intellectual property protection mechanisms required by the TRIPS Agreement to protect intellectual property. This study suggests that the two protection mechanisms are different in nature as these mechanisms protect two different subject matters of intellectual property. Most intellectual property protection mechanisms in Malaysia, including patent protection, are governed by the Intellectual Property Corporation of Malaysia (MyIPO), a statutory body that was set up in accordance to the Intellectual Property Corporation of Malaysia Act 2002, ${ }^{100}$ while

99 Trudo Lemmans and Candice Telfer, "Access to Information and the Right to Health: The Human Rights Case for Clinical Trials Transparency", American Journal of Law and Medicine 38, no.1 (2012): 63-112 at 85.

${ }^{100}$ Intellectual Property Corporation of Malaysia Act 2002 (Act 617), enforced on 3 March 2003. 
other protection mechanisms are regulated by different authorities, such as data exclusivity is regulated by the Ministry of Health and registration of plant varieties is regulated by the Ministry of Agriculture. A summary of the intellectual property involved, the relevant provisions of the TRIPS Agreement, the intellectual property protection mechanism established in Malaysia, and the laws protecting intellectual property in Malaysia as discussed in this study are illustrated in Table 1. From Table 1, it can be concluded that there is a clear difference between the patent system and data exclusivity.

Table 1: Summary of Intellectual Property Protection Mechanisms in Malaysia.

\begin{tabular}{|l|l|l|l|}
\hline $\begin{array}{l}\text { Intellectual } \\
\text { Property }\end{array}$ & $\begin{array}{l}\text { Provision in the } \\
\text { TRIPS } \\
\text { Agreement }\end{array}$ & $\begin{array}{l}\text { Intellectual } \\
\text { Property } \\
\text { Protection } \\
\text { Mechanism in } \\
\text { Malaysia }\end{array}$ & $\begin{array}{l}\text { Intellectual } \\
\text { Property Laws in } \\
\text { Malaysia } \\
\text { granting } \\
\text { Intellectual } \\
\text { Property Rights }\end{array}$ \\
\hline $\begin{array}{l}\text { Works such as } \\
\text { literary, artistic, } \\
\text { musical and } \\
\text { their related } \\
\text { works. }\end{array}$ & $\begin{array}{l}\text { Section 1: } \\
\text { Articles 9-14 }\end{array}$ & $\begin{array}{l}\text { Copyright \& } \\
\text { Related Rights } \\
\text { (automatic } \\
\text { protection system, } \\
\text { upon creation) }\end{array}$ & $\begin{array}{l}\text { Copyright Act } \\
1987\end{array}$ \\
\hline Trademarks & $\begin{array}{l}\text { Section 2: } \\
\text { Articles 15-21 }\end{array}$ & $\begin{array}{l}\text { Trademark } \\
\text { (registration } \\
\text { system) }\end{array}$ & $\begin{array}{l}\text { Trademarks Act } \\
2019\end{array}$ \\
\hline $\begin{array}{l}\text { Geographical } \\
\text { indications }\end{array}$ & $\begin{array}{l}\text { Section 3: } \\
\text { Articles 22-24 }\end{array}$ & $\begin{array}{l}\text { Geographical } \\
\text { Indications } \\
\text { (registration or } \\
\text { automatic } \\
\text { protection } \\
\text { systems) }\end{array}$ & $\begin{array}{l}\text { Geographical } \\
\text { Indications Act } \\
\text { 2000 }\end{array}$ \\
\hline $\begin{array}{l}\text { Industrial } \\
\text { designs }\end{array}$ & $\begin{array}{l}\text { Section 4: } \\
\text { Articles 25-26 }\end{array}$ & $\begin{array}{l}\text { Industrial Designs } \\
\text { (registration } \\
\text { system) }\end{array}$ & $\begin{array}{l}\text { Industrial Designs } \\
\text { Act 1996 }\end{array}$ \\
\hline Articles 27-34 & $\begin{array}{l}\text { Patent } \\
\text { (registration } \\
\text { system) }\end{array}$ & Patent Act 1983 \\
\hline
\end{tabular}




\begin{tabular}{|c|c|c|c|}
\hline Plant Varieties & $\begin{array}{l}\text { Section 5: } \\
\text { Articles 27-34 }\end{array}$ & $\begin{array}{l}\text { Plant Varieties } \\
\text { (registration } \\
\text { system) }\end{array}$ & $\begin{array}{l}\text { Protection of New } \\
\text { Plant Varieties Act } \\
2004\end{array}$ \\
\hline $\begin{array}{l}\text { Layout-designs } \\
\text { of integrated } \\
\text { circuits }\end{array}$ & $\begin{array}{l}\text { Section 6: } \\
\text { Articles 35-38 }\end{array}$ & $\begin{array}{l}\text { Automatic } \\
\text { protection system, } \\
\text { upon creation }\end{array}$ & $\begin{array}{l}\text { Layout-Designs of } \\
\text { Integrated Circuits } \\
\text { Act } 2000\end{array}$ \\
\hline $\begin{array}{l}\text { Secret } \\
\text { information }\end{array}$ & $\begin{array}{l}\text { Section 7: } \\
\text { Article 39(2) }\end{array}$ & $\begin{array}{l}\text { Automatic } \\
\text { protection as long } \\
\text { as information is } \\
\text { secret }\end{array}$ & $\begin{array}{l}\text { Common law } \\
\text { action of breach of } \\
\text { confidence is } \\
\text { available. }\end{array}$ \\
\hline $\begin{array}{l}\text { Undisclosed test } \\
\text { or other data for } \\
\text { example Tests } \\
\text { and Clinical Data }\end{array}$ & $\begin{array}{l}\text { Section 7: } \\
\text { Article 39(3) }\end{array}$ & $\begin{array}{l}\text { Data Exclusivity } \\
\text { (Government not } \\
\text { to allow clinical } \\
\text { test data to be } \\
\text { relied upon by } \\
\text { generic } \\
\text { manufacturers) }\end{array}$ & $\begin{array}{l}\text { Directive on Data } \\
\text { Exclusivity in } \\
\text { Malaysia, under } \\
\text { Regulation } 29 \text { of } \\
\text { the Control of } \\
\text { Drugs and } \\
\text { Cosmetics } \\
\text { Regulations } 1984, \\
\text { No.2, Year } 2011\end{array}$ \\
\hline
\end{tabular}

As a developing country, it is prudent to be aware of the various forms of intellectual property and the intellectual property protection mechanisms that are set up in the country, particularly for those in universities such as lecturers and researchers. Universities have often been viewed as the stepping stone for future leaders and successful business entrepreneurs and inventors, all of whom would need the knowledge on the various intellectual property and its protection mechanisms as a tool to achieve sustainable growth. This study has shown that Malaysia is a TRIPS compliance country as it has established all the intellectual property protection mechanisms required under the TRIPS Agreement through the various laws that have been put in place. The main purpose of this study is to explore the provisions of the TRIPS Agreement and conclude that data exclusivity is neither related to the patent system nor is it a TRIPS-plus provision, hence dismissing the Myths that surround data exclusivity. In this era of the Fourth Industrial Revolution, it is vital for Malaysians to realize the 
importance of intellectual property and the various intellectual property protection mechanisms available to achieve sustainability, and to compete with developed countries. This is to ensure that Malaysia will continue to prosper and improve its rankings in the GII to be amongst the top 20 countries by 2025 . 